\author{
Agnieszka KUSZEWSKA \\ University of Social Sciences and Humanities, Warsaw, Poland \\ agnieszka.kuszewska@gmail.com
}

\title{
DIFFICULT NEIGHBOURHOOD: THE KEY OBJECTIVES OF PAKISTAN'S FOREIGN POLICY TOWARDS INDIA IN THE TWENTY-FIRST CENTURY ${ }^{1}$
}

ABSTRACT What role does India play in Pakistan's international strategy? The article tackles this question and explores the crucial elements of Islamabad's policy towards India, focusing on selected internal and external security issues. Pakistani political/military leaders look upon India as its major security challenge. The alleged threat from the powerful neighbour has served as the convenient explanation for justifying enormous military expenditures and building powerful army in Pakistan, which substantially weakened democratic institutions and civilian governments and consolidated military's grip of the state power. This sense of fear was fuelled by the catastrophist mindset, claiming that India has always regarded partition of the subcontinent as a "historical aberration" and its main goal was to undo the partition or at least to subjugate Pakistan into a client-state. The protracted, war-prone relations between the two nuclear states can be defined as "difficult neighbourhood." The chapter approaches the problem of Pakistan's policy towards India in several key parts. The introduction looks at the historical developments and current internal situation in Pakistan. The first part offers an in-depth analysis of Pakistan's attitude towards the Kashmir issue, the second part analyses the strategies aimed at counterbalance India's hegemony in the region, encapsulating the phenomenon of Pakistan-China and Pakistan-U.S. relations. The last part briefly observes the

1 Work on this paper has been generously supported by the National Science Centre of Poland (NCN). Research Project: "Human rights and India's and Pakistan's policy towards Kashmir" (2012/05/B/HS5/00726). 
problem of water scarcity in India-Pakistan relations, which has a direct impact on South Asian security.

Keywords: Pakistan's foreign policy, Kashmir conflict, India-Pakistan relations

\section{INTRODUCTION}

Indian subcontinent gained independence from the British Empire in 1947 when the Indian Independence Act was enacted by the Parliament of the United Kingdom. As a result, the new state of Pakistan was carved out of colonial India on 14 August 1947. The Partition was followed by massive migrations between India and Pakistan which led to the dislocation of millions of people, separations of families, brutal communal violence on both sides and thousands of victims among desperate people who suddenly lost all their possessions and were forced out of their homeland.

Pakistan owes its existence merely to the aspirations of the Muslim League, the most influential Muslim organization in British India, led by Muhammad Ali Jinnah, who is revered in Pakistan as Quaid-i-Azam (Great Leader) or Baba-i-Qaum (Father of the Nation). His ambition was to form an independent state in the regions inhabited predominantly by the Muslim population (the eastern and western parts of British India). It was based on the so called "Two-Nation Theory," which basically assumed the unfeasibility of Muslim and Hindu groups' coexistence within one state. The claim to establish an independent state was based on the premise that Muslims of India were a nation, and therefore they were entitled to have their own sovereign state in accordance with the right to self-determination. ${ }^{2}$ The Muslim leadership assumed that in independent India the Muslim minority might be subject to persecution, unequal treatment and unable to gain its rights. Formation of the separate state was the only solution. ${ }^{3}$ The "freedom struggle," as Jinnah's adherents called it, ended with success and consequently Pakistan appeared on the region's political map as a separate entity. The Partition marked the beginning of a new era in South Asian international relations and paved the way to the most protracted conflict in contemporary international relations. Today, after almost seven decades, this unresolved issue has a debilitating impact on the South Asian region and continues to occupy centre-stage in the long-drawn bilateral dispute. ${ }^{4}$ India and Pakistan fought three wars and entered the phase of low-intensity escalation several times. Cross-border skirmishes continue on a regular basis and over the years they have claimed many victims among both Indian and Pakistani soldiers and civilians, especially those living in the vicinity of the Line of Control (the de facto cease fire line).

2 H. Yusuf, Pakistan. A Study of Political Developments 1947-1997, Lahore 1999, p. 21.

3 M. Tudor, The Promise of Power. The Origins of Democracy in India and Autocracy in Pakistan, New York 2013, pp. 94-95.

4 T.Y. Tan, G. Kudaisya, The Aftermath of Partition in South Asia, London-New York 2000, p. 221. 
The South Asian conflict led to nuclearization of the subcontinent, which prompted a quick reaction from the international community. The global perception of the potential threat is exacerbated by the fact that South Asia is the only region in the world where two nuclear neighbours are engaged in an unresolved conflict. The conflict escalation may have grave impact on regional and global security. Moreover, it has seriously influenced almost every aspect of other Indo-Pakistani bilateral relations. The powerlessness of both countries to deal successfully with other minor problems seems to be a ramification of the conflict.

Today, Pakistan is South Asian nuclear power and American ally in the so called "war on terror." It must be pointed out, however, that the relations between the two states are characterized by mutual mistrust and that they have undergone serious deterioration in recent years. It is often emphasized that the then dictator of Pakistan, General Pervez Musharraf, surrendered the state's sovereignty to the U.S. after 11 September 2001, when he joined the war on terror under pressure of Secretary of State, Collin Powell. That period paved the way to the rise of militant Islam and escalated the problem of the Pakistani Taliban. ${ }^{5}$

There were two other major turning points that aggravated Islamabad-Washington relations: when American secret forces eliminated Osama Bin Laden in May 2011 and when they started anti-Taliban drone strikes campaign along the Afghanistan-Pakistan border, on Pakistani territory. It raised fury among the majority of Pakistanis, who accused Americans of violating the state's sovereignty and territorial integrity. The future relations between the U.S. and Pakistan are hardly predictable. The anti-American criticism has become an easy way to gain massive political capital in Pakistan. Imran Khan - the cricketer-turned politician and the head of the political party Tehreek-e-Insaf is a good example. He strongly criticises the current Pakistan Muslim League government of Nawaz Sharif and in August 2014 he organized massive anti-government "Azadi March" (Freedom March) to the capital city Islamabad, escalating the internal political turmoil.

All these disturbances serve as a proof of ongoing internal challenges in Pakistan. The country is torn apart by internal disturbances and tensions: persistent rivalry between the centre (Punjab) and other provinces, sectarian violence, religious extremism, escalated by the notorious Tehrik-i-Taliban Pakistan (TTP), weakness of the civil government and democratic institutions, endless cycle of corruption, economic problems reinforced by the power cuts that plunge the country into darkness even several times a day for many hours. The military control of the state and lack of possibilities to build a self-reliant economy have strongly retarded the industrial development of Pakistan. The economic reforms have been widely neglected and Pakistan's ruling oligarchy of feudal lords, civil and military bureaucracy keep themselves separate from ordinary people, unwilling to address their growing grievances. There are already some leaders, such as Mullah Qadri or Imran Khan, who openly call on people to join the revolution against corrupt political clans. Popular anger grows and for ruling elites it may become

T. Amin-Khan, Genealogy of the Post-Colonial State in India and Pakistan, Lahore 2013, p. 166. 
the major problem to tackle in the nearest future. Pakistan needs leaders who will be able to reject the "imperialist" attitude and be able to address the needs of the society.

The assassinations of Punjab Province Governor Salman Taseer and Federal Minister for Minority Affairs and leader of Christian community, Shahbaz Bhatti (in January and March 2011), and attacks against religious minorities and their precarious situation cast additional doubts whether Pakistan's leaders would be able to blunt the growing influence of ultraconservative religious forces that continuously receive public support especially among less-educated masses. The unwillingness to do away with blasphemy law that allows to punish anyone convicted of insulting the prophet Mohammed even with death penalty, serves not only as unambiguous proof for that support, but rather as a confirmation of deeply rooted connections between political and religious elites. Taseer and Bhatti were punished for the fact that they had been openly speaking out against controversial laws. All the above-mentioned factors determined the assessment of some terrorist experts who listed Pakistan among the most serious security challenges for the foreseeable future. ${ }^{6}$ The concerns that the country is on the verge of political disintegration and international isolation are expressed on a daily basis and thus it is important to analyze Pakistan's foreign policy towards its arch enemy, India, as a part of the complexity of regional affairs, because it may have profound impact on the situation in the whole region of South Asia and even beyond, especially after the withdrawal of NATO/ISAF troops from Afghanistan.

This article provides an in-depth look at the key points of Pakistan's foreign policy towards India. Taking into consideration the complexity of regional security challenges, such analysis is a highly relevant contribution to the ongoing extensive debate on the future prospect for India-Pakistan relations and further security-related developments in South Asia. The study is focused on the following, selected problems:

- the Kashmir conflict and its role in Pakistan's policy towards India,

- India as an emerging superpower: how does Pakistan try to counterbalance this superiority?

- Pakistan's position on the matter of the alleged Indian "water terrorism."

\section{KASHMIR IN PAKISTAN'S POLICY TOWARDS INDIA}

The unresolved Kashmir conflict remains a crucial factor that deteriorates mutual relations between India and Pakistan. South Asia is one of the most volatile regions in the world as the escalation of this conflict may lead to an over-regional or even

6 In a survey carried out in December 2010 by the journal Foreign Policy, the terrorist experts were asked questions concerning contemporary security threats. In the question "Which country poses the greatest terrorist threat to the West today?" 79\% pointed out Pakistan as the most serious security risk. One of the experts acknowledged that the most dangerous terrorist in the world would be "the terrorist whose actions precipitate a war between India and Pakistan." P. Bergen, 'The FP Survey: Terrorism, Foreign Policy, 2 January 2011, at <http://www.foreignpolicy.com/articles/2011/01/02/ the_fp_survey_terrorism?page $=0,0>, 3$ August 2014 . 
global destabilization. It is also one of the key factors in Pakistan's foreign policy towards India.

From Pakistan's point of view, the resolution of Kashmir conflict is conditio sine qua non of improving relations with India. The official stance presented by subsequent governments has been challenged over the last years by an increasing internal threat: different terrorist outfits that found safe haven on Pakistani soil and were once used by the Pakistani establishment as a tool in the proxy war in Afghanistan and Kashmir, now pursue their own policy, waging jihad war against the state and its institutions. The Movement of Pakistani Taliban (Tehrik-e-Taliban Pakistan, TTP), an umbrella organization of several terrorist outfits, is the most important one. In 2014, the Pakistani government initiated peace talks with the group, but the subsequent terrorist attack (Karachi Airport in June 2014) prompted the Pakistan Army to launch military offensive operation (code-named Zarb-e-Azb - meaning "sharp and cutting strike") against the Taliban in North Waziristan region. India takes the terrorism threat from Pakistan very seriously. Islamist jihadists such as Lashkar-e-Toiba, Jaish-e-Muhammad or Hizb-ul-Mujahedin, were responsible for attacks in India (for example the Indian Parliament 2001, Mumbai 2008) and took part in a proxy war in Jammu and Kashmir.

Pakistan's claims on Kashmir are based on two general assumptions: the distribution of Muslim majority and the rule according to which the British left the subcontinent. That rule stated that the provinces inhabited by Muslim majority were supposed to be placed within Pakistani borders. Sumit Ganguly emphasizes that the founders of Pakistan treated Islam instrumentally, merely as a tool for political mobilization, the ground for the idea of "Pakistanihood," and that is why it was crucial to hold the province with the Muslim majority. ${ }^{7}$

Since the beginning of the conflict, Pakistan has made efforts to engage the international community in the resolution of the Kashmir conflict. On the website of Pakistan's Ministry of Foreign Affairs the Kashmir issue is presented as one of the crucial geostrategic challenges of the state's foreign policy. It is manifested with the emphasis on the necessity of safeguarding national security and geo-strategic interests, including Kashmir. ${ }^{8}$ Pakistan's principled position on Jammu and Kashmir is derived from the above mentioned principle of the "Two-Nation Theory" and on the UN Security Council and the UNCIP resolutions, which provide that the final disposition of Jammu and Kashmir will be made in accordance with the will of the people. Pakistan claims that these wishes should be fulfilled by holding a plebiscite in Kashmir in accordance with the above-mentioned resolutions. ${ }^{9}$ Pakistan's stance on Kashmir is historically inherited and focused on the following key objectives:

S. Ganguly, "Beyond the Nuclear Dimension: Forging Stability in South Asia," Arms Control Today, No. 4 (2001), p. 2.

8 Foreign Policy Objectives, Ministry of Foreign Affairs, Pakistan, at <http://www.mofa.gov.pk/content. php?pageID=objectives $>, 21$ August 2014 .

9 The resolutions required the withdrawal of Pakistani and Indian troops from each part of Kashmir a condition both sides have been unable and unwilling to meet. M. Gaur, Foreign Policy Annual, New Delhi 2005, p. 91. 
1. The incorporation of Kashmir to India was forced and illegal and therefore Jam$\mathrm{mu}$ and Kashmir is not an integral part of India. The legal validity of the Instrument of Accession to India, signed in 1947 by Maharaja Hari Singh is questioned. The Indian part of Kashmir is often named as "occupied" Kashmir.

2. India and Pakistan share equal position in the conflict and have the same rights and obligations towards Kashmir.

3. Kashmir is the main source of tensions between Islamabad and New Delhi. All other issues are irritants and will be easily settled once the Kashmir conflict is successfully addressed and resolved.

4. Unlike India, Pakistan perceives Kashmir as a territorial conflict.

5. The future of the state should be determined by a plebiscite held in both parts of Kashmir. Having refused to reconsider the possibility of holding a plebiscite in Jammu and Kashmir, India has showed disregard to the UN and UNCIP ${ }^{10}$ resolutions.

6. The Kashmiris' right to self-determination is a precondition of the conflict resolution.

7. There are strong ties between Pakistan and the Muslim majority in the Indian part of Kashmir (especially in the Valley of Kashmir). It's a crucial part of pan-Islamic unity.

8. Pakistan is entitled to provide Kashmiris with moral support and act as a proponent of their struggle for self-determination.

9. India commits massive human rights violations in Jammu and Kashmir, where civilians are subjected to intimidation, forced disappearances, extrajudicial killings and other repressive measures taken by Indian security forces. The sense of impunity encourages further repressions against the defenceless civilians.

10. India is responsible for thwarting the peace process and for surge in ceasefire violations along the Line of Control.

Pakistan for years denied all allegations of providing separatists in Kashmir with arms and shelter, but that sort of support has a long history. In 2010, former President General, Pervez Musharraf admitted that Pakistan had trained the militants to fight against India in Kashmir. He tried to justify that policy by claiming that The West was ignoring the resolution of the Kashmir issue, which is the core issue of Pakistan. It is the right of any country to promote its own interests when India is not prepared to discuss Kashmir at the United Nations and is not prepared to resolve the dispute in a peaceful manner. ${ }^{11}$ This state-

10 UNCIP - United Nations Commission for India and Pakistan, established by the UN Security Council in 1948 to mediate the dispute during the first Kashmir war. It was subsequently transformed into UNMOGIP - the United Nations Military Observer Group in India and Pakistan - that supervises the ceasefire between the two states until today and investigates complaints of ceasefire violations that occur on regular basis along the conflict-prone borderline. The UNMOGIP United Nations Military Observer Group in India and Pakistan at <http://www.un.org/en/peacekeeping/ missions/unmogip/background.shtml> 8 July 2014.

11 'Pakistan Is Always Seen as the Rogue, Der Spiegel, 4 October 2010, at <http://www.spiegel.de/ international/world/0,1518,721110,00.html>, 18 July 2014. 
ment was nothing new: blaming India for lack of will to resolve the conflict has been a characteristic feature of the political leadership's attitude in Pakistan.

Providing permanent support to the people in Kashmir was a necessity for Pakistani leaders, especially when military regimes took over the power in the country. The conflict served as a factor strengthening Pakistani nationalism and in order to win public support for massive defence spending (at the expense of education, healthcare, etc.) it was a justified tactic of political and military establishment to present India as a powerful, dangerous and unpredictable enemy. Conspicuously, Kashmir played an important role in strengthening the bonds of Pakistan's society, already divided by deeply-rooted ethnic and religious strife.

In Pakistani internal foreign policy the role of the intelligence agencies, particularly the Inter-Services Intelligence (ISI), is absolutely significant. Strengthened especially during the General Zia ul Haq's islamization era, ${ }^{12}$ the ISI played a crucial role in supporting Afghan jihad after the Soviet invasion in 1979. After the withdrawal of Soviet forces from Afghanistan, ISI started to smuggle ex-mujahideen from Afghanistan to Kashmir with cooperation of the Jammu and Kashmir Liberation Front. It was a turning point in escalating the anti-Indian insurgency, which began in 1989. In the early 1990s, jihadists from Afghanistan were transferred to Azad Kashmir, where new training camps were being built for them by the Pakistani Army. ${ }^{13}$ After the completion of training they were sent to the Indian part of Kashmir to support the secessionist movement there. Pakistan entered into cooperation with the newly emerged Taliban outfits, training and using them to sponsor cross-border terrorism in Indian Kashmir. The Pakistan-supported insurgency and active resistance against the Indian rule in Jammu and Kashmir brought the forgotten conflict back into the light and turned it once again into a regional flashpoint. That course of events was in conformity with Pakistan's aspirations.

The clandestine support for some terrorist outfits was not considerably curbed after 2001. Officially however, this support was restricted to "moral" and "diplomatic." In 2002, General President Musharraf emphasized emotionally: Kashmir runs in our blood. No Pakistani can afford to sever links with Kashmir... We will continue to extend our moral, political and diplomatic support to Kashmiris. We will never budge from our principle stand on Kashmir. ${ }^{14}$ Although Musharraf formally banned terrorist organizations, many of them still continue to operate. The voice of the extremists is highly unambiguous, Hafiz Abdul Rehman Makki, Jamaat-ud-Daawa's head for political affairs (in December 2010 JD was listed by the Security Council as an alias of the proscribed Lashkar-e-Toiba terrorist group) pointed out that Pakistan will not be complete unless the Muslim majority states of India become part of it. Today, some of the cross-border militants waging their insurgency merely in Federally Administered Tribal

12 H. Yusuf, Pakistan..., pp. 196-199.

13 E. Inbar, H. Frisch, Radical Islam and International Security. Challenges and Responses, New York 2008, p. 163.

14 Musharraf Speech Highlights, BBC News, 12 January 2002, at <http://news.bbc.co.uk/2/hi/south_ asia/1757251.stm>, 11 February 2014. 
Areas and in Afghanistan are deeply rooted in their long-term association with the country's military-run intelligence agencies. These agencies perceive militants' potential as a "strategic asset" in the country's expansionist campaigns both in Afghanistan, and in Jammu and Kashmir. ${ }^{15}$

The year 2008 was noteworthy in regard to Indo-Pakistan relations. Firstly, gen. Musharraf was forced by the ruling coalition to step down. He had been accused of gross misconduct and violation of the constitution; the resignation helped him to avoid the procedure of impeachment. Asif Ali Zardari, Benazir Bhutto's widower, subsequently took the presidential office. In his interview for the Wall Street Journal he pointed out that jihadist groups fighting to expel India from Kashmir are "terrorists" rather than "freedom fighters." That statement exposed him to the criticism of the country's military. Secondly, the peace process with India came to a standstill after the terrorist attacks conducted at the end of November 2008 in Mumbai that claimed almost 200 victims. That led to a freeze in bilateral relations. They were resumed in February 2010, but without any constructive results - on the contrary, they ended in mutual accusations and expressing profound mistrust. In India's point of view Pakistan did not take sufficient action against terrorism and was ultimately unwilling to punish the perpetrators of the Mumbai attacks. The Pakistan Muslim League-Nawaz (PML-N) government of Nawaz Sharif which won the 2013 elections has not made any significant breakthrough so far. The new PM focused primarily on curbing the terrorist activities of the Pakistani Taliban that has become a major and growing threat to internal security, responsible for the growing number of terrorist attacks across the country. Regardless of these challenges, in Pakistan's policy towards India, the Kashmir conflict and water problems remained crucial issues to be listed in the peace talks agenda. Taking into consideration the current state of affairs, rising threats and regional challenges, it is highly dubious that the situation will undergo any significant change in the foreseeable future.

Pakistan's policy of drawing international attention to the Kashmir issue (especially to the human rights violations by the Indian security forces in Jammu and Kashmir) seems to be a losing battle. The UN's position is quite clear and it certainly will not result in any kind of intervention. Although "concerned" with the situation in Kashmir, the UN Secretary General takes the view that any mediation can be taken into consideration only when both New Delhi and Islamabad ask for it. He announced it soon after the violent protests erupted in Jammu and Kashmir in the summer of 2010, emphasizing that as far as the role of good offices is concerned the United Nations normally takes that initiative when requested by both parties concerned. As New Delhi maintains that the conflict has to be resolved bilaterally between the involved countries, the UNSG's statement is definitely to India's advantage. From India's point of view, any international involvement in the Kashmir resolution would be tantamount to interference in its internal affairs. New Delhi has always been delicate about this issue and played a role of the stalwart defender of that stance.

15 T.R. Mohanty, 'FATA: Pernicious Policies,' South Asia Intelligence Review, Vol. 12, No. 34 (2014), at <http://www.satp.org/satporgtp/sair/Archives/sair12/12_34.htm\#assessment1 >, 26 August 2014. 


\section{HOW TO COUNTERBALANCE INDIA'S HEGEMONY IN THE REGION?}

Since its inception, Pakistan has pursued the strategy policy based on suspicion that its powerful South Asian neighbour wanted to undo the creation of Pakistan. Consequently, one of the most challenging tasks in Pakistan's foreign policy has always been the question of how to resist Indian hegemony in the region. Even a cursory comparison of both countries' potentials shows that this challenge seems to be doomed to failure. New Delhi's position has risen spectacularly over the last decade. The country witnessed a rapid economic growth that ignited its global aspirations. They are reflected in the efforts to join the UN Security Council not only for a two-year term but as a permanent member. Pakistan vehemently opposes the UNSC permanent seat for India, realizing that such scenario would drastically enhance New Delhi's position in shaping global security issues, including the future Kashmir conflict resolution. That would be a grim prospect for Pakistan. In addition, India's growing position is seriously taken into consideration by powerful actors of the international scene. It's enough to mention that during the year 2010 India hosted the leaders of all P-5 countries (UNSC permanent members). It was a clear signal of India's growing political and strategic clout in international affairs.

There seem to be three major strategies in Pakistan's foreign policy of dealing with that problem in the twenty-first century: development of the nuclear potential, involvement in Afghan war as an American "major non-NATO ally," and strategic alliance with China.

\section{Development of the nuclear potential}

India and Pakistan went overtly nuclear in May $1998^{16}$ when they conducted a tit-for-tat series of nuclear explosions, evoking - not surprisingly - international criticism and anxiety. Due to the protracted conflict and other unresolved bilateral problems there is obviously a strong interaction between Pakistani and Indian nuclear policy. Especially in Pakistan's case, the nuclear capabilities play a crucial role in the country's foreign policy towards its arch enemy. The leadership in Islamabad has definitely perceived nuclear weapon as an ultimate guarantor of Pakistan's national survival in case of Indian either nuclear or conventional attack. The nuclear potential serves as a great equalizer since it is obvious that Pakistan will never be able to match India in terms of conventional weapons. ${ }^{17}$ Its importance cannot be overestimated and Pakistan has continuously expanded its nuclear arsenal. As it turned out a few years ago, Islamabad managed to double its nuclear stockpile over the last few years. At the end of January

16 India's first nuclear explosion took place much earlier, in 1974. It was code-named as "The Smiling Buddha" to point out its peaceful character.

17 B. Chakma, 'Pakistan's Nuclear Doctrine and Command and Control System: Dilemmas of Small Nuclear Forces in the Second Atomic Age', Security Challenges Journal, Vol. 2, No. 2 (2006), pp. 121 $-127$. 
2011, the Washington Post cited a U.S. non-government analyst, who emphasized that four years earlier Pakistani nuclear stockpile had been estimated at 30-60 nuclear warheads. Now the arsenal increased to over 100 deployed weapons. India's stockpile was estimated at 60-80 warheads. Pakistan's nuclear doctrine was defined as "credible minimum deterrence" and has both Indio-centric as well as regional character. According to B. Chakma, three factors determine Pakistan's nuclear posture: the perceived level of Indian threat and necessity to maintain minimum deterrent capability, the external pressure deriving from the non-proliferation regime and the internal dynamics and domestic challenges along with the ability to generate recourses for the nuclear programme. ${ }^{18}$

Islamabad has always been sensitive on the issue of being equally treated with India by the international community as far as nuclear capability is concerned. Pakistan's nuclear capability had an impact on India's policy at least twice after 1998 when the governments in New Delhi did not take retaliatory action with conventional weapon after the escalation of mutual tensions. In the wake of the attack on Indian Parliament on December 13, 2001, ${ }^{19}$ the BJP government launched the Operation Parakram, the biggest mobilization of the Indian Army since 1971 (800,000 soldiers). The operation was soon labelled as "unfinished war," because the troops were backed in October 2002 without undertaking any military action. The nuclear factor obviously contributed to that situation. Pakistan's stance did not raise any doubts; president Musharraf announced to Atal Bihari Vaypayee, the then Indian Prime Minister, that if the Indian troops move a single step across the international border or the Line of Control, they should not expect a conventional war from Pakistan.

The resignation of retaliatory action was even more visible after the Mumbai attacks carried out in November 2008. This time the military units were not concentrated along the border. The Indian general Muhammad Malik admitted that the possibility of retaliation (against the bases of Pakistani Lashkar e-Toiba terrorist organization) was very limited because of the serious risk of an uncontrolled escalation of India-Pakistan war to the nuclear level.

\section{The involvement in the Afghan war and the relations with the U.S.}

The relations with the United States stir up enormous controversy in Pakistan. Just before retiring as the U.S. Defense Secretary, Robert Gates described the U.S. -Pakistan relations as a "bad marriage." Noticeably, the strategic/military cooperation between the two states has a long historical background in mutual rollercoaster-like relations and it dates back to the 1950s. Pakistan, being perceived as a frontline state in the war against communism, was armed with American weapons during the Cold War, especially in the 1980s, when the Asian ally obtained multi faceted aid to

18 Idem, Pakistan's Nuclear Weapons, New York 2009, p. 43.

19 Jaish-e-Mohammed terrorist organization, supported by Pakistani agencies, was responsible for this attack. 
support the Afghan mujahideen fighting against the Soviet oppression..$^{20}$ This strategic alliance was resumed after the World Trade Center attacks. The 9/11 made a critical threshold in Pakistan's foreign policy, an important turning point in the first decade of the twenty-first century. The state's strategic geographical situation predominantly contributed to the fact that General Pervez Musharraf was among the first foreign leaders to whom Washington submitted the offer of cooperation in the "war on terror." The message3474 (or rather the ultimatum) from President George W. Bush and the Secretary of State, Colin Powell, could not be more unambiguous: "you're either with us or against us." Musharraf had to choose the lesser evil and he ended ties with the Taliban, opened its bases and air space to the U.S. forces inside Pakistan for conducting operations in Afghanistan. Thus, previously discredited and portrayed as a dictator by the Western countries, the General had no option but to make this "marriage of convenience" with the U.S. Consequently, he became one of Washington's most important strategic allies in the region. ${ }^{21}$ The critics point out that by allowing the U.S. to interfere in Pakistan's internal affairs he surrendered the sovereignty of the state.

Not only did General Musharraf's decision make a turning point in the relations with the U.S., but it also paved the way to the key objectives of Pakistan's foreign policy towards India in the first decade of the twenty-first century. The dictator's choice had three serious results as far as the relations with India are concerned. Firstly, it forcibly - and at least theoretically placed Pakistan on the same side with India in the so-called "global war on terror," which might have had an impact on the mutual relations. Admittedly, they were strained at the beginning of 2002, after the terrorist attacks on the Indian Parliament in December 2001, but subsequently they entered into the de-escalation phase at the end of 2003, resulting in long-term talks at the negotiating table. These talks did not bring any significant progress on Kashmir and other problems, yet they obviously reduced the tensions between the two neighbours and introduced the de-escalation phase in mutual relations.

Secondly, it made Pakistan responsible for curbing terror on its own soil under careful international (especially Indian) surveillance. Musharraf made a promise to fight terrorism, but in India and in the West it is still widely believed that the Pakistani military retains ties with groups operating in Afghanistan and Kashmir. This enduring support for terrorist groups in Pakistan was confirmed in February 2011 by the secret cables revealed by WikiLeaks. According to the information conveyed by a senior British diplomat to the Americans, terror training camps, though not directly run by the Pakistan government, continue to operate along the India-Pakistan border creating potential for conflict with India and instability in the region. Terrorist organi-

20 R.M. Khan, Afghanistan and Pakistan. Conflict, Extremism, and Resistance to Modernity, Karachi 2011, pp. 4-7.

21 The shift in American policy was sudden and profound. The Bush administration repealed prohibitions on arms transfers to Pakistan that had been imposed following nuclear tests in 1998 and the coup that brought Musharraf to power in 1999. 
sations, like al-Qaeda, have begun using these camps as recruitment centres. After additional training ... recruitees are then poised to commit terrorist activities. ${ }^{22}$

Thirdly, it slightly exacerbated the Indo-Pakistani rivalry in the context of relation with the U.S. The pre-2001 condemnation of Musharraf was beneficial for India, but the subsequent American friendship with Pakistani dictator raised a question: who turned out to be a more important American ally and what kind of advantages could that bring? These advantages were soon to be put forward: since 2001, Pakistan has become one of the crucial recipients of the U.S. security assistance, including arms transfers. In 2004 Americans upgraded relations with Pakistan by granting the country with the "major non Nato ally" status (India does not have such privilege). Apart from arms transfers, this alliance brought significant financial benefits to Pakistan; in 2009 the Congress set aside $\$ 7.5$ billion assistance for five-year programs to develop Pakistan's infrastructure (by building roads, bridges and power plants to provide electricity, helping internally displaced persons, disaster assistance) ${ }^{23}$ In the years 2002 -2013, Pakistan received approximately $\$ 26$ billion in military and economic aid from the United States. ${ }^{24}$

On the other hand, to Pakistan's annoyance, the United States signed civil nuclear agreement with New Delhi. The agreement provided U.S. assistance and expanded mutual cooperation: India was granted eligibility for buying U.S nuclear technology. It lifted a three-decade U.S. moratorium on nuclear trade with India and was tantamount to the U.S recognition of India as world's nuclear power. In 2010, President Obama further enraged Islamabad by backing up the permanent seat for India in the UN Security Council.

As mentioned above, the strategic US-Pakistan alliance attracts growing criticism in Pakistan. There are many reasons for which the relations with the U.S are gradually deteriorating. ${ }^{25}$ The anti-American fury is clearly visible in the massive protests whenever an Afghan-Pakistan cross-border drone strike kills civilians on the Pakistani side.

22 Moreover, it was stated that Muslim parents in the U.K. used to send their "problem children" to Pakistani Azad Kashmir. These children may be responsible for future terrorist attacks in the U.K, and that is why stabilising Kashmir is also important for U.K. domestic security reasons - H. Suroor, 'Terror Training Camps Still Operating on India-Pak Border: WikiLeaks,' The Hindu, 4 February 2011, at <http://www.thehindu.com/news/national/article1156588.ece>, 8 July 2014.

23 The report released on December 31, 2010 by the Inspectors General for the U.S. State Department Defense Department and Agency for International Development (USAID), stated however that much of the aid has proved ineffective. The report provided various reasons: problems with staffing the programs, fraud, hostile security environment.

24 M. Hassan, 'Pakistan "Received \$25.91b" from US since 9/11', The Nation, 27 June 2013, at <http://www.nation.com.pk/national/27-Jun-2013/pakistan-received-25-91b-from-us-since-9-11>, 8 August 2014.

25 One of them is for example the case of the CIA contractor, Raymond Davis, detained and then released from Pakistani prison in March 2011. He was accused of shooting two Pakistani civilians who had been tailing him. The fact that he was released under American pressure and enabled to go back to the U.S. evoked massive anti-government and anti-American protests. The rage was further heightened by the U.S strikes in North Waziristan on March 17, which killed approximately 40 people. 
The massive strikes on the village of Dhatta Khel in North Waziristan were conducted in March 2011 and claimed many victims. General Ashfaq Parvez Kayani, the then Pakistan Army Chief with a strong anti-American posture, publicly labelled these attacks as human rights violations. In protest against the strikes Pakistan additionally cancelled its participation in the Trilateral (Pakistan, Afghanistan and the U.S.) Meeting on Afghanistan scheduled for March 26 in Brussels - a decision that was probably made too hastily because it was directed against Islamabad's own interests.

The Indian strategic, political and economic dominance in Afghanistan after the international troops pull out may certainly be portrayed as one of the nightmares of Pakistan's military and civilian leaders. It is also easy to determine that Pakistan's haste resignation of the alliance with the U.S. and rejection of massive financial support by a country torn currently by internal disturbances, social unrest and economic crisis, would have a negative impact on Pakistan - also in terms of Indian rivalry. Not only could it contribute to strengthening the India-U.S alliance, but it might also give New Delhi priority over Pakistan in arranging the post-conflict situation in Afghanistan. It is possible that Pakistan will further strengthen relations with China, which are already close especially in terms of strategic and military cooperation. It may prove to be essential in the situation where the "marriage of convenience" between Islamabad and Washington seems to slowly break down.

\section{Strategic alliance with China}

The military alliance between China and Pakistan has a strong historical background, which dates back to the 1960s. As the U.S. repeatedly imposed embargoes on Pakistan when it was involved in war with India (for example in 1965), Pakistan had to look for some diversification of the source of weapon. The additional factor that paved the way for the bilateral cooperation was the fact that in the 1960s India was a common enemy both for Islamabad and for Beijing. After the short boundary war between China and India in the $1960,{ }^{26}$ Beijing started to provide technical, financial and military assistance to Pakistan. China also helped Pakistan to develop and strengthen its nuclear capability.

There are two factors that undoubtedly facilitate mutual Sino-Pakistan dealings: both are used to authoritarianism and both countries' policy is dominated by the military, thus they seem to be natural allies. The year 2011 marked the $60^{\text {th }}$ anniversary of mutual diplomatic relations and it was an occasion to strengthen mutual cooperation on various levels. Joint army, air forces and naval exercises were set. To India's growing (and justified) concerns, China has been fulfilling in Pakistan its boundless strategic plans concerning its growing presence in South Asia. The Chinese have undertaken several projects in Pakistan-held Kashmir. In 2010, some reports alluded to 11,000 Chinese troops deployed at the invitation of the Pakistani government in Gilgit-Baltistan,

26 As a result of that war China gained Aksai Chin, the uninhabited but strategically important part of Kashmir. The India-China conflict over this territory has never been definitively resolved. 
a region that has been considered as part of Jammu and Kashmir. ${ }^{27}$ China strongly denied these allegations. At first, Pakistan did the same, but later admitted China's presence, explaining that they are there only to help Pakistanis affected by floods. But the presence of the Chinese People's Liberation Army in the area had a strategic aim: they helped to build a high-speed rail and road link to the Straits of Hormuz and the strategic Pakistani Gwadar Port (near the Persian Gulf). For China, the unrestricted road and rail access to the Gulf through Pakistan's territory is a key element of its policy in the region aimed at guaranteeing the possibility of quick transport of oil and gas. It is the main reason for its strategic partnership and enhanced cooperation with Pakistan. Mutual Sino-Pakistani naval drill familiarized the Chinese navy with the Straits of Hormuz..$^{28}$ It seems that Pakistan's enhanced political, military and diplomatic cooperation with China aims at debilitating India's aspirations to assume more powerful role in the region and in the world. It is within the interests of both Beijing and Islamabad to defy New Delhi's strategic objectives. China as a powerful ally may also serve as an alternative to visibly deteriorating relations between Islamabad and Washington.

\section{WATER PROBLEMS IN INDIA-PAKISTAN RELATIONS}

Another important point of friction in India-Pakistan relations is the so called "water terrorism" or "bloodless form of war" as some Pakistani policy makers dubbed it. ${ }^{29}$ It has ratcheted up the tensions so immensely merely because water plays an important role in the economy of Pakistan. The state primarily depends on agriculture accounting for $24 \%$ of the national GDP, $48 \%$ employment and $70 \%$ of country's exports. It is notable that the agriculture is entirely based on irrigation. Unfortunately, per capita availability of surface water in Pakistan is gradually dwindling from 5,650 cubic meters in 1951 , to projected 800 cubic meters in $2025 .{ }^{30}$ That may cause serious water shortage. Islamabad accuses India of building dams on rivers to cause water shortages in Pakistan in order to enfeeble its economy. To Pakistan's disadvantage, the rivers from Indus basin that water it have their origins in India (in the Indian part of Kashmir) and it has raised fear in Pakistan that by its actions India could contribute to draughts and famine.

Pakistan trumpeted the issue internationally and in 1952 approached the World Bank to help settle the problem. However, the most serious attempt to find permanent solution was made when the Indus Water Treaty was signed on September 19, 1960. It was meant to serve as a tool to avoid potential conflicts in the future. Basically, the

27 B. Roy, 'Enhanced Sino-Pak Military and Strategic Cooperation,' Chennai Centre for China Studies, 10 March 2011, at <http://www.c3sindia.org/pakistan/2186>, 19 June 2014.

28 Ibid.

29 S. Shaukat, 'India's Water Terrorism,' The Nation, 15 February 2010, at <http://www.nation.com. $\mathrm{pk} /$ pakistan-news-newspaper-daily-english-online/Opinions/Columns/15-Feb-2010/Indias-water-terrorism>, 25 July 2014.

30 Staff Country Reports. Pakistan: Poverty Reduction Strategy Paper, International Monetary Fund, Washington 2010, p. 227. 
treaty regulated the use of rivers and canals between the two countries. Pakistan obtained exclusive rights for the three western rivers: Indus, Jhelum and Chenab. India's rights were restricted to the three eastern rivers, namely Ravi, Beas and Sutlej. Special commissioners were appointed on both sides to observe the situation and express their views and doubts when necessary. Moreover, the treaty guaranteed a decade of uninterrupted water supply. During this period Pakistan built dams, financed by long-term World Bank loans and compensation money from India. A system of eight inter-river link canals and three huge multipurpose dams: Warsak, Mangla and Tarbela were constructed.

Today, Pakistan claims that the treaty gave India a superior position. Islamabad looked with concern at the construction of some controversial dams by India such as the Sallal Dam, the Wullar Barrage or the Baglihar Dam, pointing out that it is a violation of the Indus Water Treaty. Islamabad strongly objects to the Kishanganga Dam, Indian hydroelectric project on Neelam River ${ }^{31}$ with its completion scheduled for 2016, pointing out that it will adversely affect the agricultural land in Azad (which means "free") Kashmir, by reducing and averting the flow of water. But Pakistan does not restrict itself to airing its grievances and takes an active part in the race for water. It is constructing its own Neelam-Jhelum project - to be completed by 2017. It is located near Muzaffarabad, the capital of the Pakistan's part of Kashmir. Its aim is to divert water from the Neelam River in order to generate electricity. Both projects have one thing in common: they both exploit natural resources of Jammu and Kashmir and will have disastrous environmental and economic effects for the local people.

Pakistan's policy makers described "water terrorism" as one of the most contentious issues in mutual relations. The Chairman of Pakistan's Indus Water Council, Zahoorul Hassan Dahir, emphasized: India is trying to establish its full control over the Indus River and deprive Pakistan from its share of water. After Chenab and Jhelum now India is pursuing a plan to get complete control over Indus River. He even added that problems of terrorism, insurgency and Talibanization were created intentionally to divert attention from "Indian water terrorism". ${ }^{32}$ For some radicals, such as Hafiz Muhammad Saeed, the leader of the terrorist organization Lashkar-e-Toiba/Jamaat-ud-Daawa, Pakistan will have to counter India's aggression by using force, because India imposed war on Islamabad.

On February 22, 2011, the U.S. Senate's Foreign Relations Committee issued a warning concerning "water wars" between India and Pakistan. ${ }^{33}$ It points out that new dam on the Indian side could give New Delhi the ability to deny Pakistan its share of

31 Kishanganga is another name of that river. It flows to Azad Kashmir from the Indian side and joins with Jhelum River near Muzaffarabad, the capital of Pakistani Kashmir.

32 'Indian Water Terrorism: Greater Threat Than Taliban: Pakistan', Thaindian News, 5 May 2009, at <http://www.thaindian.com/newsportal/south-asia/indian-water-terrorism-greater-threat-than-taliban-pakistan_100188486.html>, 15 August 2014.

33 Pakistan's Ministry of Foreign Affairs responded to the U.S. Senate report two days after it had been released. It stated that Pakistan has conveyed its concerns to India through the Office of Permanent Indus Commission [...]. These concerns are required to be addressed in a sincere, forthwith and result-oriented 
Indus waters at crucial moments in the growing season. The water dispute may add to the mistrust between the neighbours and lead to regional instability. ${ }^{34}$

India strongly rejected the accusations of the treaty violations. G. Rangathan, Indus Water Commissioner from India declared that India had been affected as much as Pakistan due to water shortage in the Indus. That was not enough to convince Pakistan. Pakistan's Foreign Minister Shah Mehmood Qureshi underlined the importance of the issue while talking about the revival of Pak-India talks. For Pakistan the construction of the Krishanganga project over the Neelam River is a clear sign that India wants to use its leverage with Pakistan on the Kashmir issue. What is more, India's "water terrorism" is not restricted only to the Indus Basin. There are suspicions in Pakistan that India secretly offered technical assistance to the government in Afghanistan to build and maintain the Sarobi Dam over the Kabul River, near the Pak-Afghan border. These actions further besmirched the image of India in Pakistan and assured the latter of New Delhi's hostile aims. There were even allegations (barely believable) that the gates of the dams (the Sarobi Dam and those situated in Indian Kashmir) were deliberately opened to cause the disastrous flood that devastated Pakistan in 2010.

Water-related problems appear every time bilateral talks are held. But so far little progress has been made over the issue. Both countries are unwilling either to postpone or to give up their projects, so the reasonable solution is still up in the air; Pakistan's stance does nothing more to advance that goal than India does.

\section{CONCLUSION: FUTURE PROSPECTS}

Pakistan's foreign policy towards India cannot be studied only in terms of their bilateral relations. It's a part of a broad-spectrum policy and Pakistani leaders take into consideration the complexity of strategic environment in the region on the one hand and the variety of internal challenges on the other. The Kashmir conflict, which continuously poses a serious threat to international security, will presumably remain unresolved in the foreseeable future. The resumption of bilateral dialogue may further de-escalate the conflict, but neither Pakistan nor India is willing to give up their historically and strategically grounded attitudes. Moreover, the post-2014 situation is highly unpredictable. Pakistan faces increasing extremism and sectarian strife. The targeted attacks against religious and ethnic minorities take place on a regular basis in various parts of Pakistan.

The government of Nawaz Sharif badly needs success in the anti-Taliban campaign. The outlawed TTP which proclaims its goal to transform Pakistan into a state based on Sharia Law has the same agenda for the whole subcontinent. Potential spread of

manner - Response in US Senate Report: Water War in South Asia, Ministry of Foreign Affairs, Government of Pakistan, at <http://www.mofa.gov.pk/pr-details.php?prID=873>, 2 July 2014.

34 Avoiding Water Wars: Water Scarcity and Central Asia's Growing Importance for Stability in Afghanistan and Pakistan, US Senate Committee on Foreign Relations, 22 February 2011, at <http://www. foreign.senate.gov/publications/download/s-prt-112-10-avoiding-water-wars-water-scarcity-and-centrals-asias-growing-importance-for-stability-in-afghanistan-and-pakistan>, 17 July 2014. 
terrorist violence, exacerbated with the NATO troops' withdrawal from Afghanistan and strengthening the position of the Taliban, may have profound impact on India-Pakistan relations. Some Indian leaders have already expressed their grave concern at the risk of major influx of the Taliban extremists to the Indian part of Kashmir. Apart from Kashmir, water is one of the main sources of instability in South Asia. New regulations are necessary - the water treaty needs to be revised to avoid future tensions. The problem should be viewed also in terms of climate change that often leads to water scarcity. Without mutual guarantees there is little chance to alleviate the long-term distrust between the two neighbours.

Afghanistan/Pakistan-India rivalry are inseparable parts of contemporary and future security problems in the region. Both India and Pakistan have a profound interest in shaping the future situation on the Afghan soil. The cooperation with Kabul after coalition troops are backed up is one of the major strategic concerns for New Delhi and Islamabad. It is a part of Islamabad's foreign policy challenge: the will to counterbalance India in the region. No matter how the situation will be solved it already constitutes potential source of future serious disturbances in the region. Pro-India Afghanistan would definitely raise the sense of insecurity in Pakistan. That is one of the reasons why Pakistan strives to strengthen its ties with China. Regardless of further cooperation with either the U.S. or China, or both, Pakistani leaders must not forget the fact, that for superpowers the ally in Islamabad is needed merely to fulfil their own interests.

There is a serious question one must ask while observing the current political turmoil in Pakistan: who has got the exclusive privilege to determine Islamabad's foreign policy objectives? Throughout Pakistan's history, civil government has been weak and often treated with contempt and anger by public opinion. There is little doubt who has a trump card in Pakistani foreign policy: it has always been the preserve of the army and it even seems to have exacerbated after 2007, when General Ashfaq Kayani took over as the Chief of Army Staff of Pakistan (COAS). In December 2010, WikiLeaks cables revealed that Kayani told the U.S. ambassador in 2009 that he had been planning to pressure the then civilian president Asif Ali Zardari to resign. ${ }^{35}$

New Delhi is perceived by Pakistani establishment as an arch enemy and rival in Afghanistan. It is also accused of giving military and financial support to separatists in Balochistan. ${ }^{36}$ Kyani's successor, General Raheel Sharif, who took over the COAS post in November 2013, continues the policies of his predecessor. In such circumstances it is doubtful whether the Pakistani military is willing to seek peace with India within the next few years. They will rather try to bring any areas of potential conflict into light; apart from Kashmir, "water terrorism" is a perfect candidate.

The liberals' position in Pakistan has been definitively weakened by the assassination of Punjab's Governor Salman Taseer on January 4, 2011 and Shahbaz Bhatti, Pa-

35 'WikiLeaks: Kayani Plotted to Topple Zardari,' Rediff News, 2 December 2010, at <http://www. rediff.com/news/slide-show/slide-show-1-wikileaks-kayani-planned-to-topple-zardari/20101201. htm>, 6 July 2014.

36 Pakistan accuses India of transferring weapons, explosives and money to the militants in that troubled area. India rejects these accusations. 
kistan's minorities minister (the only Christian minister in the Pakistani government), on March 1 the same year. Both had spoken against the country's draconian blasphemy laws and received death threats from the Pakistani Taliban. Farahnaz Ispahani, an aide to the then President Asif Ali Zardari, rightly described it as concerted campaign to slaughter every liberal, progressive and humanist voice in Pakistan.

The growing strength of radical Islamists in Pakistan is particularly alarming for India because it poses a serious threat to its security. Unpredictable and unstable Pakistan stands in contrast to the long-term interest of India. But in terms of the resumption of the talks with Pakistan, Indian leaders also must face serious challenges. New Delhi wants to hold "a composite dialogue," but Narendra Modi, the Indian Prime Minister, representing the Hindu nationalist party, BJP, does not want to present a "soft" attitude towards Pakistan. The talks, when resumed, will be held in extremely difficult circumstances with the ongoing trust-deficit on both sides and skirmishes along the Line of Control.

The state authoritarianism creates favourable conditions for violence to arise or to exacerbate. ${ }^{37}$ Such effect appears merely when it is accompanied by additional factors. In Pakistan's case there is a lot to choose from: terrorism, sectarian violence, economic problems, lack of products on the market, constant power cuts, incompetence and corruption among elites and civilian governments (which is an "invitation" for the military to seize power), but more importantly the foreign policy problems: the "war on terror," the course of events in Afghanistan, the relations with the U.S., and, last but not least, the relations with India taken in their entirety and exemplified in this article.

Pakistan's long-term foreign strategy should become gradually less Indio-centric. The future leaders, either civilian or military will have to determine what role in the region is in conformity with Islamabad's aspirations. The catastrophist mindset, claiming that India has always regarded partition of the subcontinent as a "historical aberration" and its main goal was to undo the partition or at least to subjugate Pakistan into a client-state, seems to be hugely overrated and serves rather as a political tool to strengthen the position of the military establishment in Pakistan. The democratic Pakistani government, eager to develop regional economic cooperation, is in accordance with India's interests. It is barely believable that India would like to absorb Pakistan and undo the partition. For Pakistan there are other, real challenges to tackle: it has to pursue economic reforms, set up future relations with Washington and Kabul and strengthen its cooperation with China which should be founded on mutually beneficial principles. But still, one of the crucial issues in Pakistan's foreign policy is to resolve disputes with India. Strengthening economic ties with the "difficult neighbour" will be profitable for both countries and may contribute to reducing the long-term mutual distrust. It has been proved without doubt that the present almost insignificant volume of $\$ 2.6$ billion trade between India and Pakistan can be multiplied to $\$ 10$ billion by normalizing trade relations, improving infrastructure on both sides of the borders, opening new routes and easing bureaucratic obstacles. Moreover, the trade which goes through

37 J. Hippler, 'Pakistan - Ein gescheiterter Staat?' in B. Chiari, C. Schetter (eds.), Pakistan, München 2010, p. 226 (Wegweiser zur Geschichte). 
Dubai would also be much more beneficial if diverted through official channels - both states could earn tax revenues. Both New Delhi and Islamabad have no option but to work in tandem; the South Asian Association for Regional Cooperation (SAARC) may serve as a suitable platform for such cooperation. "All necessary steps will be taken to restore peace and put Pakistan on the track of progress and prosperity" according to the words of Prime Minister Nawaz Sharif. ${ }^{8}$ Taking into consideration current internal problems with terrorism and sectarian violence, and the entirety of challenges of Pakistan's foreign policy, it will be exceedingly difficult for Islamabad to draw up the appropriate and effective modus operandi and to improve its image on the international scene.

\section{BIBLIOGRAPHY}

Amin-Khan T., Genealogy of the Post-Colonial State in India and Pakistan, Lahore 2013. Avoiding Water Wars: Water Scarcity and Central Asia's Growing Importance for Stability in Afghanistan and Pakistan, US Senate Committee on Foreign Relations, 22 February 2011, at <http:// www.foreign.senate.gov/publications/download/s-prt-112-10-avoiding-water-wars-water-scarcity-and-centrals-asias-growing-importance-for-stability-in-afghanistan-and-pakistan>.

Bergen P., 'The FP Survey: Terrorism,' Foreign Policy, 2 January 2011, at <http://www.foreignpolicy.com/articles $/ 2011 / 01 / 02 /$ the_fp_survey_terrorism?page $=0,0>$.

Chakma B., 'Pakistan's Nuclear Doctrine and Command and Control System: Dilemmas of Small Nuclear Forces in the Second Atomic Age,', Security Challenges Journal, Vol. 2, No. 2 (2006).

Chakma B., Pakistan's Nuclear Weapons, New York 2009.

Foreign Policy Objectives, Ministry of Foreign Affairs, Pakistan, at <http://www.mofa.gov.pk/ content.php?pageID=objectives $>$.

Ganguly S., 'Beyond the Nuclear Dimension: Forging Stability in South Asia,'Arms Control Today, No. 4 (2001).

Gaur M., Foreign Policy Annual, New Delhi 2005.

Ghumman K., 'Cabinet Approves National Security Policy', Dawn, 27 February 2014.

Hassan M., 'Pakistan “Received \$25.91b” from US since 9/11', The Nation, 27 June 2013, at $<$ http://www.nation.com.pk/national/27-Jun-2013/pakistan-received-25-91b-from-us-since-9-11>.

Hippler J., 'Pakistan - Ein gescheiterter Staat?' in B. Chiari, C. Schetter (eds.), Pakistan, München 2010 (Wegweiser zur Geschichte).

Inbar E., Frisch H., Radical Islam and International Security. Challenges and Responses, New York 2008.

'India Imposed War on Pak by Constructing Illegal Dams: Saeed, The Indian Express, 7 March 2010, at <http://www.indianexpress.com/news/india-imposed-war-on-pak-by-constructing-ill/587880/>.

38 K. Ghumman, 'Cabinet Approves National Security Policy,' Dawn, 27 February 2014; Foreign Policy Objectives, pp. 1, 5 . 
'Indian Water Terrorism: Greater Threat Than Taliban: Pakistan', Thaindian News, 5 May 2009, at <http://www.thaindian.com/newsportal/south-asia/indian-water-terrorism-greater-threat-than-taliban-pakistan_100188486.html>.

Khan R.M., Afghanistan and Pakistan. Conflict, Extremism, and Resistance to Modernity, Karachi 2011.

Mohanty T.R., 'FATA: Pernicious Policies', South Asia Intelligence Review, Vol. 12, No. 34 (2014), at <http://www.satp.org/satporgtp/sair/Archives/sair12/12_34.htm\#assessment1>.

Musharraf Speech Highlights, BBC News, 12 January 2002, at <http://news.bbc.co.uk/2/hi/ south_asia/1757251.stm>.

'Pakistan Is Always Seen as the Rogue', Der Spiegel, 4 October 2010, at <http://www.spiegel.de/ international/world/0,1518,721110,00.html>.

'Pakistan Says Jammu and Kashmir not Integral Part of India,' India Today, 11 October 2011, at $<$ http://indiatoday.intoday.in/story/pakistan-says-jammu-and-kashmir-not-integral-part-of-india/1/154476.html>.

Response in US Senate Report: Water War in South Asia, Ministry of Foreign Affairs, Government of Pakistan, at <http://www.mofa.gov.pk/pr-details.php?prID=873>.

Roy B., 'Enhanced Sino-Pak Military and Strategic Cooperation,' Chennai Centre for China Studies, 10 March 2011, at <http://www.c3sindia.org/pakistan/2186>.

Shaukat S., 'India's Water Terrorism', The Nation, 15 February 2010, at <http://www.nation.com.pk/pakistan-news-newspaper-daily-english-online/Opinions/Columns/15-Feb-2010/Indias-water-terrorism>.

StaffCountry Reports. Pakistan: Poverty Reduction Strategy Paper, International Monetary Fund, Washington 2010.

Suroor H., 'Terror Training Camps Still Operating on India-Pak Border: WikiLeaks,' The Hin$d u, 4$ February 2011, at <http://www.thehindu.com/news/national/article1156588.ece>.

Tan T.Y., Kudaisya G., The Aftermath of Partition in South Asia, London-New York 2000.

Tudor M., The Promise of Power. The Origins of Democracy in India and Autocracy in Pakistan, New York 2013.

UNMOGIP. United Nations Military Observer Group in India and Pakistan, at <http://www. un.org/en/peacekeeping/missions/unmogip/background.shtml>.

'WikiLeaks: Kayani Plotted to Topple Zardari', Rediff News, 2 December 2010, at <http://www.rediff. $\mathrm{com} /$ news/slide-show/slide-show-1-wikileaks-kayani-planned-to-topple-zardari/20101201. htm>.

Yusuf H., Pakistan. A Study of Political Developments 1947-1997, Lahore 1999.

Agnieszka KUSZEWSKA, Ph.D. is an Associate Professor of Political Science at the University of Social Sciences and Humanities (Department of Social Sciences and Humianities). She is also an expert on South Asia at Warsaw-based think tank Poland-Asia Research Centre and member of European Security Institute (EIB). Her area of expertise concerns contemporary international relations, international conflicts, terrorism, security dilemmas, foreign/internal policy strategies and the role of South Asia (particularly India and Pakistan) in international affairs. She has published many articles, policy papers in these areas, as well as three monographs (in Polish). 